\title{
Evaluasi Aktivitas Antibakteri Sediaan Plester Ekstrak Daun Petai Cina (Leucaena Leucocephala) Terhadap Bakteri Staphylococcus AureusAttc 25923 Pk/5
}

\author{
Eka Sri Rahayu ${ }^{1 *}$, w Wirasti $^{2}$, SSlamet $^{3}$, Dwi Bagus Pambudi ${ }^{4}$ \\ 1,2,3,4 Sarjana Farmasi, Universitas Muhammadiyah Pekajangan Pekalongan, Indonesia \\ *email:ekakakakku998@gmail.com
}

\begin{abstract}
Chinese petai plants contain alkaloids that have antibacterial abilities including Staphylococcus aureusATTC 25923 PK/5 bacteria. Plaster is a dosage form whose active ingredients need to be developed from natural ingredients, especially Chinese petai leaves. The purpose of this study was to optimize the plaster of Chinese petai leaf extract and antibacterial Staphylococcus aureusATTC $25923 \mathrm{PK} / 5$ and to determine the antibacterial activity of the extract plaster with various doses. The test method for antibacterial is the well method. The data obtained is the diameter of the inhibitory power of the extract in the plaster. Data analysis to determine antibacterial activity using spss. The results of the phytochemical test showed that the Chinese petai leaf extract contained active compounds, namely tannins, saponins, alkaloids, flavonoids and steroids. Chinese petai leaf extract was also able to inhibit Staphylococcus aureusATTC 25923 PK/5bacteria in the extract obtained an inhibition zone of $5.1 \mathrm{~mm}$ at a concentration of $25 \%$ and plaster obtained an inhibition zone of $3.46 \mathrm{~mm}$, a concentration of $50 \%$ obtained an inhibitory zone diameter of $5.63 \mathrm{~mm}$ and at plaster obtained an inhibition zone diameter of $4.5 \mathrm{~mm}$, a concentration of $75 \%$ obtained an extract inhibition zone diameter of $6.56 \mathrm{~mm}$ on plaster obtained an inhibition zone diameter of $5.53 \mathrm{~mm}$, a concentration of $100 \%$ obtained an extract inhibition zone diameter of $7 \mathrm{~mm}$ and on plaster The diameter of the inhibition zone was $6.46 \mathrm{~mm}$. This shows that the Chinese petai leaf extract has potential as an antibacterial against the growth of Staphylococcus aureusATTC 25923 PK/5bacteria.
\end{abstract}

Keywords: Chinese Petai, Extract, Plaster, Antibacterial

\begin{abstract}
Abstrak
Tanaman petai cina mengandung alkaloida yang memiliki kemampuan sebagai antibakteri diantaranya bakteri Staphylococcus aureusATTC 25923 PK/5. Plester merupakan bentuk sediaan yang bahan aktifnya perlu dikembangkan dari bahan alam terutama daun petai cina. Tujuan penelitian ini melakukan optimasi plester ekstrak daun petai cina dan antibakteri Staphylococcus aureusATTC $25923 \mathrm{PK} / 5$ dan mengetahui aktivitas antibakteri plester ekstrak dengan berbagai dosis. Metode uji terhadap antibakteri adalah metode sumuran. Data yang didapatkan adalah diameter daya hambat ekstrak dalam plester. Analisis data untuk mengetahui aktivitas antibakteri menggunakan ANOVA. Hasil uji fitokimia menunjukkan bahwa ekstrak daun petai cina memiliki kandungan senyawa aktif, yakni tanin, saponin, alkaloid, flavonoid dan steroid. Ekstrak daun petai cina juga mampu menghambat bakteri Staphylococcus aureusATTC 25923 PK/5pada ekstrak didapatkan zona hambat sebesar 5,1 $\mathrm{mm}$ pada konsentrasi $25 \%$ dan plester didapatkan zona hambat sebesar $3,46 \mathrm{~mm}$, konsentrasi 50\%didapatkan diameter zona hambat ekstrak sebesar 5,63 mm dan pada plester didapatkan diameter zona hambat sebesar $4,5 \mathrm{~mm}$, konsentrasi $75 \%$ didapatkan diameter zona hambat ekstrak sebesar $6,56 \mathrm{~mm}$ pada plester didapatkan diameter zona hambat sebesar 5,53 mm, konsentrasi $100 \%$ didapatkan diameter zona hambat ekstrak sebesar $7 \mathrm{~mm}$ dan pada plester didapatkan diameter zona hambat sebesar 6,46 mm. Hal ini
\end{abstract}




\section{Prosiding Seminar Nasional Kesehatan Lembaga Penelitian dan Pengabdian Masyarakat Universitas Muhammadiyah Pekajangan Pekalongan}

menunjukkan bahwa ekstrak daun petai cina memiliki potensi sebagai antibakteri terhadap pertumbuhan bakteri Staphylococcus aureusATTC 25923 PK/5.

Kata kunci:Petai Cina, Ekstrak, Plester, Antibakteri

\section{Pendahuluan}

Staphylococcus aureus ATTC 25923 PK/5umumnya hidup pada kulit dan membran mukosa manusia.Merupakan jenis bakteri yang sering menyebabkan infeksi pada manusia. Hampir setiap orang akan mengalami beberapa tipe infeksi Staphylococcus aureus ATTC 25923 PK/5sepanjang hidupnya, dari infeksi kulit ringan, keracunan makanan, sampai infeksi berat [10]. Daun petai cina (Leucaena leucocephala) merupakan tumbuhan yang mengandung alkaloida, saponin, lektin, flavonoid, tanin, mimosin, leukanin, protein, kalsium, fosfor, besi, asam lemak, serat vitamin A dan vitamin B. Daun petai cina (Leucaena leucocephala) dapat digunakan sebagai antibakteri karena mengandung senyawa aktif leupol. Berbagai kandungan yang terdapat dalam daun petai cina diperkirakan sebagai antiinflamasi dan antioksidan adalah flavanoid.Sementara lektin berfungsmenstimulasi pertumbuhan sel kulit, alkaloida berfungsi sebagai antimikroba [8].

Banyaknya tanaman yang berkhasiat sebagai obat di daerah pedesaan di Indonesia.Alam menyediakan bahan alami dan ekonomis yang berasal dari tanaman. Salah satu tanaman yang dapat digunakan sebagai obat tradisional adalah daun petai cina (Leucaena leucocephala), daun petai cina memiliki kegunaan dalam kehidupan sehari-hari yaitu dapat digunakan sebagai obat luka baru dan bengkak dengan cara daunnya dikunyah atau digerus lalu ditempelkan pada luka.

Keuntungan penggunaan plester yaitu mudah digunakandapat menutup dan melindungi berbagai macam jenis luka. Selama tidak ada bahan asing yang masuk ke dalam luka, plester dapat mengurangi risiko infeksi dan trauma jaringan [9].

\section{Metode}

Penelitian ini menggunakan metode eksperimental laboratory.Variabel bebas dalam penelitian ini adalah ekstrak daun petai cina (Leucaena leucocephala) dan variabel terikat adalah diamater zona hambat pertumbuhan bakteri Staphylococcus aureus ATTC 25923 PK/5.

\section{Hasil dan Pembahasan}

\section{Hasil}

Penelitian ini dilakukan dari bulan mei 2021 sampai dengan juli 2021, tempat penelitian determinasi tanaman dilakukandi Laboratorium Biologi Fakultas MIPA Universitas Ahmad Dahlan.Pembuatan ekstrak daun petai cina dan skrining fitokimia dilaksanakan di Laboratorium Fitokimia Program Studi sarjana Farmasi Universitas Muhammadiyah Pekajangan Pekalongan.Penelitian uji aktifitas bakteri dilaksanakan di Laboratorium Mikrobiologi dan Teknologi Sediaan Steril Program Studi Sarjana Farmasi Universitas Muhammadiyah Pekajangan Pekalongan.Pembuatan sediaan plester dilaksanakan di Laboratorium Mikrobiologi dan Teknologi Sediaan Steril Program Studi Sarjana Farmasi Universitas Muhammadiyah Pekajangan Pekalongan. 


\section{Prosiding Seminar Nasional Kesehatan 2021 Lembaga Penelitian dan Pengabdian Masyarakat Universitas Muhammadiyah Pekajangan Pekalongan}

\section{Alatdan Bahan}

Botol maserasi, rotary evaporator, Laminar Air Flow, neraca analitik, labu vaporasi, cawan penguap, pinset, batang pengaduk, alat-alat gelas, micropipet, oven, kapas, jarum ose, autoklaf, inkubator, mistar, corong, labu ukur, cawan petri, kain flanel, toples kaca, plat kaca.

Etanol 96\%, $\mathrm{H}_{2} \mathrm{SO}_{4}$, kloroform, $\mathrm{FeCl}_{3}$, DMSO (dimethylsulfoxide), obat sofratulle ${ }^{\mathrm{R}}$, $\mathrm{NaCl}$ 0,9\%, eter, asam asetat anhidrat, serbuk magnesium, amil alkohol, pereaksi mayer, dragendrof, wagner, Nutrient Agar, Nutrient Broth, kertas cakram steril, alumunium foil, biakan bakteri Staphylococcus aureus ATTC 25923 PK/5, bantalan kasa steril, plester (Hansaplast).

\section{Pembahasan}

\section{Determinasi tanaman}

Pada penelitian ini tanaman yang digunakan adalah daun petai cina (Leucaena leucocephala (Lamk) de Wit).penelitian dilakukan dilaboratorium fitokimia dan mikrobiologi Fakultas IImu Kesehatan Universitas Muhammadiyah Pekajangan Pekalongan.

\section{Pengambilan Dan Pengolahan Sampel}

Daun petai cina pada penelitian ini berasal dari desa Kandangserang, Kecamatan Kandangserang, Kabupaten Pekalongan. Pengambilan daun dilakukan secara manual dengan mengambil bagian daun yang segar dan berwarna hijau. Daun petai cina yang digunakan berasal dari satu pohon di satu tempat, hal tersebut bertujuan agar tidak terjadi variasi kandungan senyawa pada tanaman yang dapat disebabkan oleh adanya perbedaan kondisi tanah, lingkukan dan unsur hara dari tempat tanaman berasal [6].Kemudian daun dipisahkan dari tangkainya untuk memperoleh daun petai cina sebanyak $5 \mathrm{~kg}$. Duan petai cina yang akan digunakan selanjutnya disortasi basah untuk dipisahkan dari kotoran-kotoran dan bahan asing, kemudian dicuci dengan air mengalir untuk menghilangkan kotoran yang melekat pada biji petai cina [7]. Selanjutnya dilakukan penirisan dan pengeringan. Tujuan dilakukan penirisan adalah untuk mengurangi atau menghilangkan kandungan air dipermukaan bahan setelah proses pencucian sedangkan tujuan dilakukan proses pengeringan adalah untuk mengurangi kadar air agar bahan simplisia tidak rusak dan dapat disimpan dalam jangka waktu yang lama, menghentikan reaksi enzimatis serta mencegah pertumbuhan kapang, jamur dan jasad renik lain [5]. Proses pengeringan daun petai cina dengan dijemur ditutupi kain hitam, bertujuan untuk mengurangi sinar UV yang dapat merusak senyawa dalam bahan yang dikeringan [4].

Proses selanjutnya adalah proses penghalusan dan penyaringan. Proses ini bertujuan untuk mendapatkan serbuk simplisia yang homogen dan untuk mempermudah penarikan senyawa zat aktif simplisia yang dapat digunakan sebagai antibakteri [3]. Daun petai cina dihaluskan dengan menggunakan blender dan disaring dengan ayakan mesh 40. 


\section{Prosiding Seminar Nasional Kesehatan 2021 Lembaga Penelitian dan Pengabdian Masyarakat Universitas Muhammadiyah Pekajangan Pekalongan}

\section{Pembuatan ekstrak dengan metode maserasi}

Proses ekstraksi dilakukan dengan cara merendam 500 gram serbuk daun petai cina dengan pelarut etanol 96\% (1:3). Pada penelitian ini etanol dipilih dua non polar diharapkan dapat menarik senyawa yang bersifar polar. Dasar pemilihan pelarut yang lain yaitu, kemudahan penggunaan, efesiens, selektivitas dan penerapan yang luas [1]. Proses maserasi dilakukan selama 5 hari dengan bantuan pengadukan, kemudian dilanjutkan proses remaserasi selama 2 hari. Proses tersebut bertujuan agar senyawasenyawa aktif dapat diambil secara optimal [3]. Filtrat hasil maserasi dipekatkan dengan menggunakan rotary evaporator dengan suhu $50^{\circ} \mathrm{C}$ sehingga diperoleh ekstrak kental sebanyak 50 gram dengan hasil rendemen ekstrak 0,1\%.

\section{Uji penapisan skrining fitokimia ekstrak daun petai cina}

\begin{tabular}{|c|c|c|c|c|}
\hline No & Uji Tabung & Pereaksi & hasil & Keterangan \\
\hline 1. & Uji terpenoid & Klorofom dan $\mathrm{H}_{2} \mathrm{SO}_{4}$ & & Endapan hitam \\
\hline 2. & Uji tanin & $\mathrm{FeCl}_{3} 0,1 \%$ & & Biru kehitaman \\
\hline 3. & Uji saponin & Air $+\mathrm{HCl}$ & & Terbentuk buih \\
\hline 4. & Uji alkaloida & $\begin{array}{l}\text { Etanol } 70 \% \text { dan } \mathrm{HCl} 2 \mathrm{~N} \\
\text { - reagen mayer } \\
\text { - reagen dragendrof }\end{array}$ & & $\begin{array}{l}\text { - endapan putih } \\
\text { - endapan coklat } \\
\text { kemerahan }\end{array}$ \\
\hline 5. & Uji flavonoid & $\mathrm{Mg}$ dan $\mathrm{HCl}$ & & Merah bata \\
\hline 6. & Uji steroid & Eter dan $\mathrm{H}_{2} \mathrm{SO}_{4}$ pekat & & Hijau \\
\hline
\end{tabular}

Hasil uji penapisan fitokimia ekstrak daun petai cina terbukti mengandung senyawa tanin, saponin, alkaloid, flavonoid dan steroid.Ekstrak daun petai cina positif memiliki kandungan tanin karena perubahan warna sebelum ditetesi besi (III) dari kuning menjadi hitam keunguan.Penambahan ekstrak dengan $\mathrm{FeCl}_{3} 1 \%$ dalam air menimbulkan warna hijau, merah, ungu atau hitam yang kuat. Terbentuknya warna hitam keunguan pada ekstrak setelah ditambahkan $\mathrm{FeCl}_{3} 1 \%$ karena tanin akan bereaksi dengan ion Fe3+ membentuk senyawa kompleks [2].

Hasil pengujian fitokimia senyawa saponin menunjukkan bahwa ekstrak daun petai cina positif karena ada busa stabil yang terbentuk. Menurut Harbone (1978) uji reagen yang positif akan menimbulkan busa yang mantap ketika dikocok dengan air, busa merupakan bukti adanya senyawa saponin dalam sampel.

Uji golongan senyawa flavonoid dilakukan untuk mengetahui keberadaan senyawa flavonoid dalam ekstrak daun petai cina.Uji flavonoid dilakukan dengan etanol $70 \%$, serbuk $\mathrm{Mg}$ dan $\mathrm{HCl}$ pekat digunakan untuk menghidrolisis flavonoid menjadi aglikonnya, yaitu dengan menghidrolisis O-glikosil. Flavonoid tereduksi dengan $\mathrm{Mg}$ dan $\mathrm{HCl}$ dapat memberikan warna merah, kuning atau jingga (Baud ,2014). Hasil pengujian menunjukkan ekstrak daun petai cina positif mengandung flavonoid yang ditandai adanya warna merah.

Uji senyawa alkaloida dilakukan dengan menggunakan reagen dragendrorf dan mayer. Pada pereaksi dragendrof dan mayer terjadi perubahan warna yaitu dragendrof terdapat endapan merah, pada pereaksi mayer terdapat endapan putih yang menandakan senyawa murni yang diperoleh positif terhadap alkoloid. Suatu senyawa 


\section{Prosiding Seminar Nasional Kesehatan 2021 Lembaga Penelitian dan Pengabdian Masyarakat Universitas Muhammadiyah Pekajangan Pekalongan}

positif terhadap steroid apabila berwarna biru atau hijau, sedangkan terpenoid berwarna merah atau ungu.

Uji Aktivitas Antibakteri

\begin{tabular}{|c|c|c|c|c|c|}
\hline \multirow[t]{2}{*}{ konsentrasi } & \multicolumn{3}{|c|}{ Diameter (mm) } & \multirow[t]{2}{*}{ Rata-rata $\pm \mathrm{SD}$} & \multirow[t]{2}{*}{ kriteria } \\
\hline & 1 & 2 & 3 & & \\
\hline $25 \%$ & 5,2 & 5,0 & 5,1 & $5,1 \pm 0,1$ & sedang \\
\hline $50 \%$ & 5,3 & 5,6 & 6,0 & $5,63 \pm 0,351$ & sedang \\
\hline $75 \%$ & 6,4 & 6,5 & 6,8 & $6,56 \pm 0,208$ & sedang \\
\hline $100 \%$ & 6,9 & 7,0 & 7,3 & $7 \pm 0,208$ & sedang \\
\hline $\begin{array}{l}\text { Kontrol positif } \\
\text { (sofratulle) }\end{array}$ & 13,8 & 14,1 & 13,1 & 13,6 & Kuat \\
\hline Kontrol negatif & 0 & 0 & 0 & 0 & $\begin{array}{c}\text { Tidak ada } \\
\text { zona } \\
\text { hambat }\end{array}$ \\
\hline \multirow[t]{2}{*}{ konsentrasi } & \multicolumn{3}{|c|}{ Diameter $(\mathrm{mm})$} & Rata-rata $\pm \mathrm{SD}$ & kriteria \\
\hline & 1 & 2 & 3 & & \\
\hline $25 \%$ & 3,5 & 3,1 & 3,8 & $3,46 \pm 0,354$ & Lemah \\
\hline $50 \%$ & 3,8 & 4,1 & 4,4 & $4,5 \pm 0,3$ & Lemah \\
\hline $75 \%$ & 5,6 & 5,3 & 5.7 & $5,53 \pm 0,208$ & sedang \\
\hline $100 \%$ & 7,4 & 7 & 5 & $6,46 \pm 1,285$ & sedang \\
\hline $\begin{array}{l}\text { Kontrol positif } \\
\text { (sofratulle) }\end{array}$ & 10 & 11,9 & 10,8 & 10,9 & Kuat \\
\hline Kontrol negatif & 0 & 0 & 0 & 0 & $\begin{array}{c}\text { Tidak ada } \\
\text { zona } \\
\text { hambat }\end{array}$ \\
\hline
\end{tabular}

Berdasarkan hasil pengamatan didapatkan uji daya hambat ekstrak daun petai cina dan sediaan plester ekstrak petai cina terhadap bakteri Stahylococcus aureus ATTC $25923 \mathrm{PK} / 5$. Pada ekstrak daun petai cina dengan konsentrasi yaitu yang paling rendah $25 \%$ mengahasilkan zona hambat $5,1 \mathrm{~mm}$ dan konsentrasi paling tinggi $100 \%$ dengan zona hambat $7 \mathrm{~mm}$. Kontrol positif obat sofratulle yang isinya antibiotik framycetin diperoleh zona hambat yang paling besar dibanding konsentrasi yang lain yaitu 13,6 mm. Dan hasil pengamatan uji daya hambat sediaan plester ekstrak petai cina terhadap bakteri Stahylococcus aureus ATTC 25923 PK/5. Sama halnya dengan ekstrak daun daun petai cina pada sediaan plester juga terdapat zona hambat antibakteri dengan konsentrasi yaitu yang paling rendah $25 \%$ mengahasilkan zona hambat 3,46 mm dan konsentrasi paling tinggi $100 \%$ dengan zona hambat $6,46 \mathrm{~mm}$. Kontrol positif obat sofratulle yang isinya antibiotik framycetin diperoleh zona hambat yang paling yaitu $10,9 \mathrm{~mm}$. Berdasarkan uraian diatas dapat disimpulkan bahwa zona hambat akstrak daun petai cina dan sediaan plester memiliki zona hambat antibakteri yang berbeda dalam konsentrasi yang sama. Zona hambat ekstrak daun petai cina lebih besar dibandingkan zona hambat antibakteri sediaan plester.

\section{Hasil Analisis Data Sediaan Plester}

Uji normalitas Kolmogorov-Smirnov pada sediaan plester $0,298>\mathrm{p}(0,05)$ yang artinya data berdistribusi normal. Setelah diketahui data normal, maka dilanjutkan uji homogenitas pada plester $0,014>p(0,05)$ hal ini menunjukkan bahwa data tidak 


\section{Prosiding Seminar Nasional Kesehatan 2021 Lembaga Penelitian dan Pengabdian Masyarakat Universitas Muhammadiyah Pekajangan Pekalongan}

homogen. Kemudian dilanjutkan dengan ANOVA one way test.Berdasarkan analisis statistik dengan ANOVA one way test diperoleh nilai signifikansi $0,000<$ <.p $(0,01)$.

\section{Kesimpulan}

Ekstrak daun petai cina (Leucaena leucocephala (Lamk) de Wit) memiliki potensi sebagai antibakteri terhadap pertumbuhan bakteri Staphylococcus aureus ATTC 25923 $\mathrm{PK} / 5$. Kadar hambat minimum yang dihasilkan oleh ekstrak daun petai cina yaitu pada konsentrasi $25 \%$ pada plester 3,46 mm.Dari hasil analisis data sediaan plester Berdasarkan analisis statistik dengan ANOVA one way test diperoleh nilai signifikansi $0,000<. p(0,01)$.

\section{Referensi}

[1] Dai, J., Mumper, J., 2010, Plant Phenolics :Extraction, Analysis and Their Antioxidant and Anticancer Properties, Molecules, 15, 7313-7352.

[2] Harborne, J. B., 1987. Metode fitokimia penuntun cara modern menganalisis tumbuhan. Bandung: Penerbit ITB.

[3] Hidayaturahmah, Rizky, 2016. Formulasi dan uji efektivitas antiseptik gel ekstrak etanolik daun sirih merah (Piper crocatum Ruiz. and Pav.) Karya Tulis Ilmiah. Fakultas Ilmu Kedokteran dan Ilmu Kesehatan. Universitas Muhammadiyah Yogyakarta

[4] Nuria2, M.C., A. Faizatun., dan Sumantri. 2009. Uji Antibakteri Ekstrak Etanol Daun Jarak Pagar (Jatropha cuircas L) terhadap Bakteri Staphylococcus STIKES Muhammadiyah Pekajangan Pekalongan 59aureus ATCC 25923, Escherichia coli ATCC 25922, dan Salmonella typhi ATCC 1408. Jurnal Ilmu -ilmu Pertanian. 5: $26-37$.

[5] Ningsih, A. P., Nurmiati \& Agustien, A., 2013. Uji aktivitas antibakteri ekstrak kental tanaman pisang kepok kuning (Musa paradisiaca Linn.) terhadap Staphylococcus aureus dan Escherichia coli. Jurnal Biologi Universitas Andalas (J. Bio. UA.), II(3), p. 207-213

[6] Rahardjo, M., Darwati, I., Shusena, A., 2006, Produksi dan mutu simplisia purwoceng berdasarkan lingkungan tumbuh dan umur tanaman, Jurnal Bahan Alam Indonesia, 5 ,310 - 316.

[7] Rivai, H., Febrikesari, G., Fadhilah, H., 2014. Pembuatan dan karakterisasi ekstrak kering herba sambiloto (Andrographis paniculata Nees.). Jurnal Farmasi Higea. VI(1), p. 19-28

[8] Vifta, R.L, Wansyah, M.A., Hati, A.K, 2017. Perbandingan Total Rendemen Dan Skrining Antibakteri Ekstrak Etanol Daun Sirih Hijau (piper betle L) Secara Mikrodilusi. Journal Of Science And Applicative Technology, 1(2), 90

[9] Edlich RF, Reddy VR. 2001.Revolutionary advances in woundrepair inemergency medicine duringthe last three decades. J Emerg Med,20(2): 167-193.

[10] Otto Soemarwoto, Analisis Mengenai Dampak Lingkungan, Gadjah Mada University, Yogyakarta, 2010, hlm.18-19 